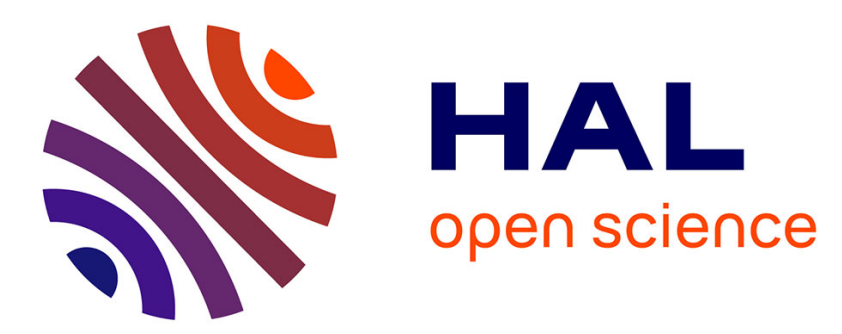

\title{
Improving sewage sludge ultrasonic pretreatment under pressure by changing initial $\mathrm{pH}$
}

Ngoc Tuan Le, Carine Julcour-Lebigue, Berthe Ratsimba, Henri Delmas

\section{To cite this version:}

Ngoc Tuan Le, Carine Julcour-Lebigue, Berthe Ratsimba, Henri Delmas. Improving sewage sludge ultrasonic pretreatment under pressure by changing initial pH. Journal of Environmental Management, 2013, vol. 128, pp. 548-554. 10.1016/j.jenvman.2013.06.001 . hal-00875470

\section{HAL Id: hal-00875470 \\ https://hal.science/hal-00875470}

Submitted on 22 Oct 2013

HAL is a multi-disciplinary open access archive for the deposit and dissemination of scientific research documents, whether they are published or not. The documents may come from teaching and research institutions in France or abroad, or from public or private research centers.
L'archive ouverte pluridisciplinaire HAL, est destinée au dépôt et à la diffusion de documents scientifiques de niveau recherche, publiés ou non, émanant des établissements d'enseignement et de recherche français ou étrangers, des laboratoires publics ou privés. 


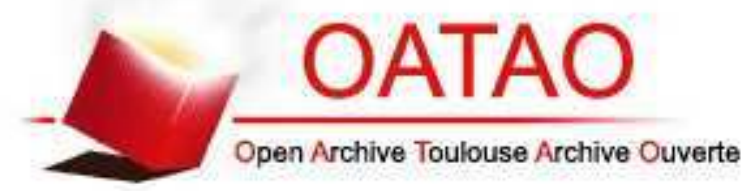

\section{Open Archive TOULOUSE Archive Ouverte (OATAO)}

OATAO is an open access repository that collects the work of Toulouse researchers and makes it freely available over the web where possible.

This is an author-deposited version published in : http://oatao.univ-toulouse.fr/ Eprints ID : 9768

To link to this article : DOI:10.1016/j.jenvman.2013.06.001

URL : http://dx.doi.org/10.1016/j.jenvman.2013.06.001

To cite this version : Le, Ngoc Tuan and Julcour-Lebigue, Carine and Ratsimba, Berthe and Delmas, Henri. Improving sewage sludge ultrasonic pretreatment under pressure by changing initial pH. (2013) Journal of Environmental Management, vol. 128 . pp. 548-554.

ISSN 0301-4797

Any correspondance concerning this service should be sent to the repository administrator: staff-oatao@ listes-diff.inp-toulouse.fr 


\title{
Improving sewage sludge ultrasonic pretreatment under pressure by changing initial $\mathrm{pH}$
}

\author{
Ngoc Tuan Le, Carine Julcour, Berthe Ratsimba, Henri Delmas* \\ Université de Toulouse, Laboratoire de Génie Chimique, INP-ENSIACET, 31030 Toulouse, France
}

\begin{abstract}
A B S T R A C T
This work aimed at understanding the combined effect of sludge $\mathrm{pH}$, temperature, and external pressure on the efficiency of sewage sludge ultrasound (US) pretreatment. Based on the evolution of both the degree of sludge disintegration ( $\mathrm{DD}_{\mathrm{COD}}$ ) and $\mathrm{pH}$, application of $40 \mathrm{mg} \mathrm{NaOH}_{\mathrm{T}} / \mathrm{g}_{\mathrm{Ts}}$ during $30 \mathrm{~min}$ was selected for chemical pretreatment. Mechanical and thermal effects induced by cavitation contributed in similar proportion to sludge disruption, but the role of the latter effect tended to be weakened after mild alkalisation of sludge. When applying external pressure, $\mathrm{DD}_{\mathrm{COD}}$ was always improved, by about $10 \%$ at the optimal value of 2 bar. The optimal combination was an addition of $40 \mathrm{mg}_{\mathrm{NaOH}} / \mathrm{g}_{\mathrm{TS}}$ prior to adiabatic sonication at 2 bar, resulting in a DD $D_{\text {COD }}$ value of about $46 \%$ at $75,000 \mathrm{~kJ} / \mathrm{kg}_{\mathrm{TS}}$ (as compared to $35 \%$ for sole US) for the investigated mixed sludge. Very short time US application yielded a drastic reduction of the volume mean particle size, mainly due to the erosion and disruption of large flocs ( $>90 \mu \mathrm{m})$, yet this was not sufficient to initiate significant subsequent COD solubilisation under stirring.
\end{abstract}

\author{
Keywords: \\ Alkalization \\ Sonication \\ Sludge disintegration \\ Chemical oxygen demand \\ Particle size distribution \\ Mixed sludge
}

\section{Introduction}

The first objective of sewage sludge treatment is to remove organic matters and water, which reduces the volume and mass of sludge and also cuts down toxic materials and pathogens. Biological, mechanical, chemical methods and thermal hydrolysis have been listed as popular techniques for sludge pretreatment (Carrère et al., 2010). Among these techniques, anaerobic digestion (AD) is the most traditional one. However, this process is limited by long sludge retention time and rather low overall degradation efficiency. Sludge mainly consists of microbial cells that limit the biodegradability of intracellular organic matters by their walls (Kim et al., 2010). Therefore, sludge disintegration pretreatment, which disrupts sludge flocs, breaks cell walls, and facilitates the release of intracellular matters into the aqueous phase, can be considered as a simple approach for improving rate and/or extent of degradation.

Ultrasonication (US) is a promising applicable mechanical disruption technique for sludge disintegration and microorganism lyses. However, US requires high energy input, generally referred as the specific energy input (ES) in $\mathrm{kJ} / \mathrm{kg}$ of dried sludge, and causes great discussions due to economic issues in practical application. This high cost could be reduced by the combination with other

\footnotetext{
* Corresponding author. Tel.: +33 (0) 5343236 78; fax: +33 (0) 534323697 . E-mail address: henri.delmas@ensiacet.fr (H. Delmas).
}

pretreatment methods, the adjustment of sludge properties (total solid content (TS), $\mathrm{pH}$, and volume of sludge, etc.), and/or the optimisation of ultrasonic parameters (frequency, specific energy input, intensity, density, etc.), and external pressure, etc.

According to Pilli et al. (2011), the effects of sonication parameters and sludge properties on solubilisation of the chemical oxygen demand (COD) can be rated as follows: sludge $\mathrm{pH}>$ sludge concentration $>$ ultrasonic intensity $>$ ultrasonic density. This suggests that $\mathrm{pH}$ adjustment to a suitable value prior to US pretreatment is an important step.

Sludge cells were proved to be disintegrated and dissolved by acidic treatment. Only the acid dose significantly affected the solubilisation of sludge (Woodard and Wukash, 1994). The optimal pH values for reducing volatile suspended solids and excess sludge subsequently varied between 1.5 (Woodard and Wukash, 1994) and 3 (Neyens et al., 2003). However, acidic pretreatment alone exhibited a very low performance as compared to US pretreatment for releasing organic matters into the liquid phase. Moreover, sludge acidification was detrimental to US pretreatment performance, especially at low pH values (Apul, 2009).

On the other hand, alkaline pretreatment enhanced sludge solubilisation, anaerobic biodegradability, and methane production (Kim et al., 2003; Valo et al., 2004). Besides, the combination of alkaline and US gave better performances of TS solubilisation as compared to both thermo-acidic and US-acidic pretreatments (Liu et al., 2008). Moreover, Chu et al. (2001) showed that 
extracellular polymeric substances (EPS) and gels surrounding cells limit the efficiency of ultrasonic treatment on sludge disintegration. Adjusting the $\mathrm{pH}$ of sludge to alkali value promotes EPS hydrolysis and gel solubilisation. After that, cell walls cannot maintain an appropriate turgor pressure (Jin et al., 2009) and easily disrupt. Therefore, the combined alkaline-US pretreatment, based on different mechanisms of sludge disintegration (modification of structural properties and intense mechanical shear force), is expected to take advantage of both and achieve a better efficiency of sludge pretreatment. Some synergetic effects were even noticed (Kim et al., 2010). In near-neutral pH conditions ( $\mathrm{pH} 7-8$ ), waste activated sludge (WAS) solubilisation obtained from combined, chemical, and US $(1.9 \mathrm{~W} / \mathrm{mL}, 60 \mathrm{~s})$ pretreatments was $18,13.5$, and $13 \%$, respectively (Bunrith, 2008). At higher $\mathrm{pH}$ values ( $\mathrm{pH} 11-13$ ), the solubilisation reached $60-70 \%$ with the combined method (ES $7500-30,000 \mathrm{~kJ} / \mathrm{kg}_{\mathrm{TS}}$ ) while it never exceeded $50 \%$ in individual pretreatments (Jin et al., 2009; Kim et al., 2010). Methane production yield derived from full stream combined-pretreated sludge (pH 9, ES $7500 \mathrm{~kJ} / \mathrm{kg}_{\mathrm{TS}}$ ) was also 55\% higher than that from the control (Kim et al., 2010).

The chemicals used for increasing the pH of sludge also affect WAS solubilisation efficacy: $\mathrm{NaOH}>\mathrm{KOH}>\mathrm{Mg}(\mathrm{OH})_{2}$ and $\mathrm{Ca}(\mathrm{OH})_{2}$ (Kim et al., 2003; Jin et al., 2009). $\mathrm{Ca}^{2+}$ and $\mathrm{Mg}^{2+}$ are key substances binding cells with EPS. As a result, their presence may enhance the reflocculation of dissolved organic polymers (Jin et al., 2009), leading to a decrease in soluble COD. On the other hand, overconcentration of $\mathrm{Na}^{+}$(or $\mathrm{K}^{+}$) was reported to cause subsequent inhibition of $\mathrm{AD}$ (Carrère et al., 2010).

For ambient conditions of US process, modification of external pressure was proved to change cavitation intensity (Thompson and Doraiswamy, 1999), and to improve the rate and yield of US-assisted reactions (Cum et al., 1988). However, most US experiments have been carried out at atmospheric pressure; only a few studies have been focussing on how increasing static pressure affects cavitation but they almost concern sonoluminescence. To our knowledge, we have conducted the first study about the effect of pressure (116 bar) on sludge US pretreatment (Le et al., 2013). We found an optimum pressure of 2 bar for sludge disintegration regardless of ES $\left(P_{\mathrm{US}}\right.$ of $\left.150 \mathrm{~W}\right)$, temperature, and sludge type. At this optimum pressure and over the ES range of 7000-75000 kJ $/ \mathrm{kg}_{\mathrm{TS}}$, adiabatic US was more efficient than isothermal US (with an improvement of 22$82 \%, 39-88 \%$, and $33-86 \%$ for mixed, secondary, and digested sludge, respectively). These conditions were therefore applied in the present work for the mixed sludge. Solubilisation of COD, evolution of $\mathrm{pH}$, and evolution of particle size distribution were examined for separate, then combined, US and alkaline pretreatments.

\section{Materials and methods}

\subsection{Sludge samples}

Mixed sludge was collected after centrifugation from Ginestous wastewater treatment plant (Toulouse, France) with a sufficient amount for all experiments in this work. Its properties, given in Table 1, were evaluated according to standard analytical methods (see $\S 2.3$ ).

It was sampled in $100 \mathrm{~g}$ plastic boxes and preserved in a freezer. Kidak et al. (2009) reported that this preliminary maintaining step might change some physical characteristics of the sludge, but it should not significantly affect COD solubilisation results. It was confirmed in this work, the difference in sludge disintegration between fresh sludge (without freezing) and frozen sludge was less than $5 \%$ on the whole ES range $\left(7000-75,000 \mathrm{~kJ} / \mathrm{kg}_{\mathrm{TS}}\right)$.

When performing experiments, the required amount of sludge was defrosted and diluted with distilled water up to $500 \mathrm{~mL}$ per
Table 1

Characteristics of the sludge sample.

\begin{tabular}{ll}
\hline Parameter & Value \\
\hline Raw sludge & \\
$\mathrm{pH}$ & 6.3 \\
Total solids (TS) & $270 \mathrm{mg} / \mathrm{g}$ \\
Volatile solids (VS) & $233 \mathrm{mg} / \mathrm{g}$ \\
VS/TS & $86.2 \%$ \\
Synthetic sample & \\
Total solids (TS) & $28.0 \mathrm{~g} / \mathrm{L}$ \\
SCOD & $19.6 \mathrm{~g} / \mathrm{L}$ \\
Total COD $0.5 \mathrm{M}$ & $38.9 \mathrm{~g} / \mathrm{L}$ \\
\hline
\end{tabular}

experiment. According to our previous results (Le et al., 2013), the optimum TS concentration for sludge ultrasonic disintegration was $28 \mathrm{~g} / \mathrm{L}$.

\subsection{Ultrasound application to original or alkalized sludge}

The US stainless steal reactor $(9 \mathrm{~cm}$ internal diameter and $18 \mathrm{~cm}$ height) consisted of a cup-horn type transducer (35 mm diameter probe) and was connected to a pressurized $\mathrm{N}_{2}$ bottle (Fig. 1). The sludge solution was stirred by a Rushton type turbine of $32 \mathrm{~mm}$ diameter, with an adjustable speed up to $3000 \mathrm{rpm}$. Cooling water was allowed to circulate in an internal coil to maintain a constant temperature $\left(T=28 \pm 2{ }^{\circ} \mathrm{C}\right)$ during isothermal sonication tests.

The US system had a fixed frequency of $20 \mathrm{kHz}$, and a maximum total power of $200 \mathrm{~W}$ corresponding to an ultrasonic power input $\left(P_{\mathrm{US}}\right)$ of $158 \mathrm{~W}$. The transducer was cooled by compressed air during operation.

US tests were performed at the highest $P_{\mathrm{US}}(150 \mathrm{~W})$ as it proved to be the most effective in isothermal conditions. A convenient stirrer speed of $500 \mathrm{rpm}$, as also found in previous work, was applied in all tests.

For each experiment, a constant volume of synthetic sludge sample $(0.5 \mathrm{~L})$ was poured into the stainless steel reactor. Five different sonication times corresponding to five values of ES ( 7000 , $12,000,35,000,50,000$, and $75,000 \mathrm{~kJ} / \mathrm{kg}_{\mathrm{TS}}$ ) were tested.

$\mathrm{ES}=\left(P_{\mathrm{US}} * t\right) /\left(V^{*} \mathrm{TS}\right)$

with ES: specific energy input, energy per total solid weight $(\mathrm{kJ} /$ $\left.\mathrm{kg}_{\mathrm{TS}}\right), P_{\mathrm{US}}$ : US power input (W), $t$ : sonication duration (s), $V$ : volume of sludge $(\mathrm{L})$, and TS: total solid concentration $(\mathrm{g} / \mathrm{L})$.

According to previous studies (Kim et al., 2003; Jin et al., 2009), $\mathrm{NaOH}$ was used for adjusting the $\mathrm{pH}$ of sludge. Regarding the treatment sequence, "alkalisation followed by ultrasonic pretreatment" was more effective than the reverse combination, as it allows the US treatment to benefit from the weakening of the sludge matrix. Conversely, the disrupted floc fragments could be reaggregated into compact structures by the subsequent $\mathrm{NaOH}$ treatment (Jin et al., 2009). Consequently, the former procedure was chosen for alkaline-US experiments.

A given amount of $\mathrm{NaOH}$ was added into the fixed volume of sludge to ensure the same condition of chemical application. The kinetics of sludge disintegration by $\mathrm{NaOH}$ was first investigated to select a convenient a holding time corresponding to the most significant COD release (cf. $\S 3.1 .1$ ). Sonication was then applied to alkalized sludge samples and the effects of $\mathrm{NaOH}$ dose, ES in the range of $0-75,000 \mathrm{~kJ} / \mathrm{kg}_{\mathrm{TS}}$, temperature profile (isothermal/adiabatic conditions), and external pressure (atmospheric pressure/optimal pressure of 2 bar in accordance with previous results) were examined in order to improve sludge disintegration. 


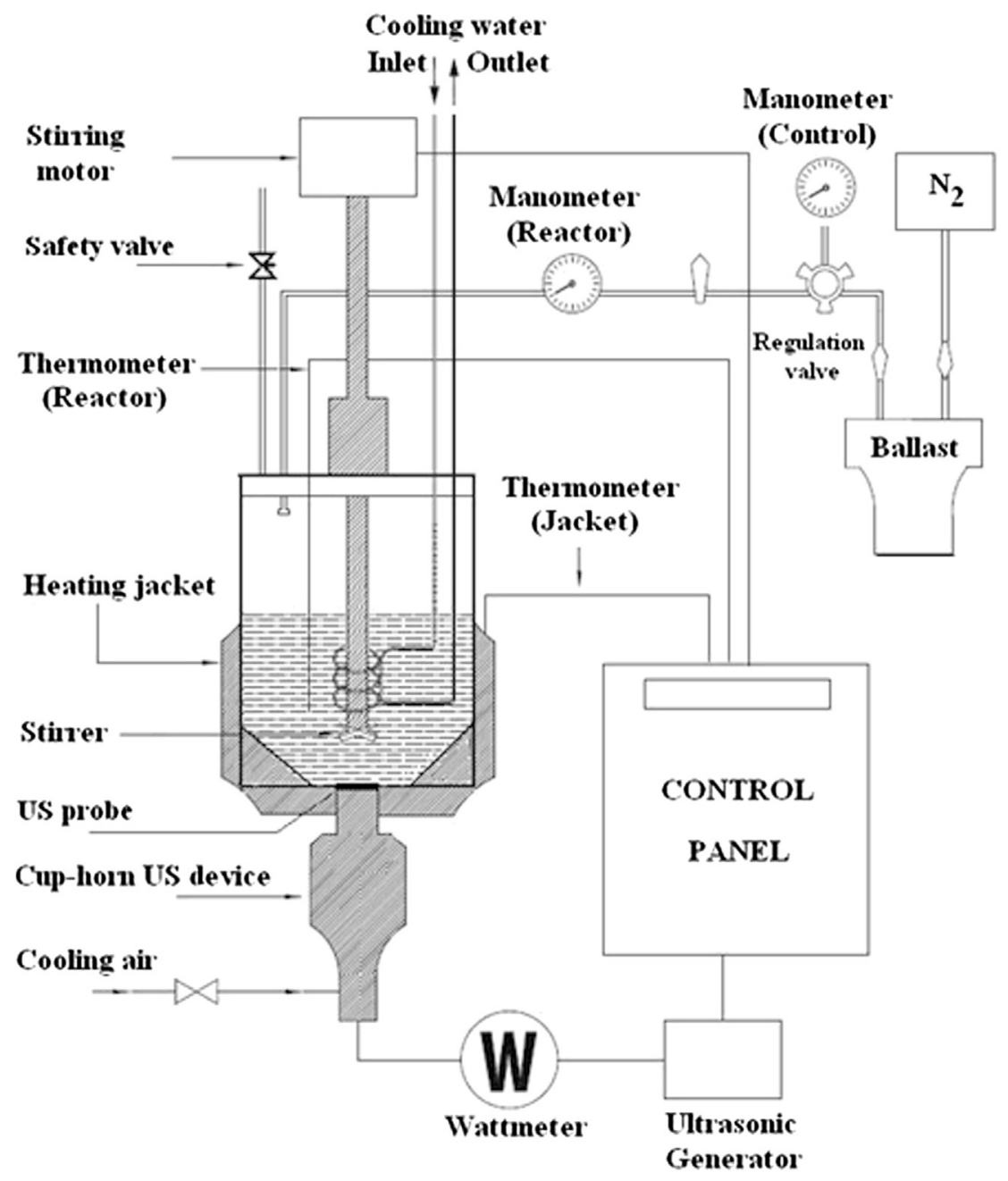

Fig. 1. Ultrasonic autoclave set-up.

\subsection{Analytical methods}

Total and volatile solid contents (TS and VS, respectively) were measured according to the following procedure (APHA, 2005): TS was determined by drying a well-mixed sample to constant weight at $105{ }^{\circ} \mathrm{C}$ and VS was obtained from the loss on ignition of the residue at $550{ }^{\circ} \mathrm{C}$.

The degree of sludge disintegration $\left(\mathrm{DD}_{\mathrm{COD}}\right)$ was calculated by determining the soluble chemical oxygen demand after strong alkaline disintegration of sludge $\left(\mathrm{SCOD}_{\mathrm{NaOH}}\right)$ and the chemical oxygen demand in the supernatant before and after treatment $\left(\mathrm{SCOD}_{0}\right.$ and SCOD, respectively):

$\mathrm{DD}_{\mathrm{COD}}=\left(\mathrm{SCOD}-\mathrm{SCOD}_{0}\right) /\left(\mathrm{SCOD}_{\mathrm{NaOH}}-\mathrm{SCOD}_{0}\right) * 100(\%)$

(Nickel and Neis, 2007).

To measure the $\mathrm{SCOD}_{\mathrm{NaOH}}$, used as a reference to evaluate the efficiency of organic matter solubilisation under US/chemical treatment, the sludge sample was mixed with $0.5 \mathrm{M} \mathrm{NaOH}$ at room temperature for $24 \mathrm{~h}$ (Li et al., 2009). Besides, total chemical oxygen demand (TCOD) was also measured by potassium dichromate oxidation method (standard AFNOR NFT 90-101).

Prior to SCOD determination, the supernatant liquid obtained after sedimentation was filtered under vacuum using a cellulose nitrate membrane with $0.2 \mu \mathrm{m}$ pore size. The filtered liquid was subjected to COD analysis as per Hach spectrophotometric method.
The change in the SCOD indirectly represents the quantity of organic carbon that has been transferred from the cell content (disruption) and solid materials (solubilisation) into the external liquid phase of sludge. The experiments were triplicated and the coefficients of variation (CV) were about $5 \%$.

The particle size distribution (PSD) of sludge before and after treatment was determined by using a Malvern particle size analyzer (Mastersizer, 2000; Malvern Inc.), a laser diffraction-based system (measuring range from 0.02 to $2000 \mu \mathrm{m}$ ). Each sample was diluted approximately 300 -fold in osmosed water, before being pumped into the measurement cell (suction mode). The PSD was based on the average of five measurements showing deviations of less than $3 \%$. Optical properties of the material were set as default (refractive index 1.52, absorption 0.1) appropriate for the majority of naturally occurring substances (Minervini, 2008; Bieganowski et al., 2012). Only in the small particle range (i.e. for particle diameter smaller than $10 \mu \mathrm{m}$ ), the refractive index dependence becomes significant (Govoreanu et al., 2009). Moreover it was checked that these mean optical properties led to a weighted residual parameter of less than $2 \%$ as recommended by the manufacturer.

Since the primary result from laser diffraction is a volume distribution, the volume mean diameter $D[4,3]$ (or de Brouckere mean diameter) was used to illustrate the mean particle size of sludge. 


\section{Results and discussion}

\subsection{Effect of chemical pretreatment on $D D_{C O D}$}

The effect of chemical pretreatment on $\mathrm{DD}_{\mathrm{COD}}$ was investigated by adding $\mathrm{NaOH}$ doses of $22,40,47$, and $77 \mathrm{mg}_{\mathrm{NaOH}} / \mathrm{g}_{\mathrm{TS}}$ to the mixed sludge solution (for comparison, $714 \mathrm{mg} \mathrm{NaOH}_{\mathrm{N}} / \mathrm{g}_{\mathrm{TS}}$ were used for the measurement of the reference $\mathrm{SCOD}_{\mathrm{NaOH}}$ ). These samples were labelled sol. 22, sol. 40, sol. 47, and sol. 77, respectively. The evolution of $\mathrm{pH}$ and $\mathrm{DD}_{\mathrm{COD}}$ of the samples, measured at room temperature, is shown in Table 2.

\subsubsection{Kinetics of alkaline sludge disintegration and effect of $\mathrm{NaOH}$ dose}

According to Kim et al. (2010), chemical pretreatment usually acts faster than other methods. Indeed, in all cases, alkaline treatment resulted in a fast solubilisation of COD, more than $50 \%$ of the maximal observed yield being achieved within $10 \mathrm{~min}$, followed by a quasi-plateau after $30 \mathrm{~min}$. Therefore, a holding time of $30 \mathrm{~min}$ was selected for subsequent experiments combined with US. During this period, the $\mathrm{pH}$ of the sludge samples dropped by about one $\mathrm{pH}$ unit as shown in Table 2.

$\mathrm{DD}_{\mathrm{COD}}$ increased continuously with $\mathrm{NaOH}$ dose in the investigated range. However, for overall process economy (related to chemicals used in pretreatment stage as well as in subsequent neutralisation required for $\mathrm{AD}$ ), $\mathrm{NaOH}$ addition should be limited. Moreover, high concentrations of $\mathrm{Na}^{+}$were reported to cause subsequent inhibition of $\mathrm{AD}$ (Carrère et al., 2010). Recommended values for $\mathrm{NaOH}$ dose vary between 50 and $200 \mathrm{mg}_{\mathrm{NaOH}} / \mathrm{g}_{\mathrm{TS}}$ to ensure that $\mathrm{NaOH}$ is in excess and achieves a significant enhance-

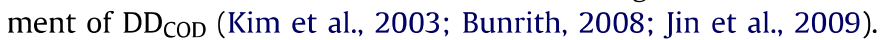
However, after $30 \mathrm{~min}, \mathrm{DD}_{\mathrm{COD}}$ value from sol. 40 was almost double of that from sol. 22, but close to that from sol. 47. In other words, an increase of the $\mathrm{NaOH}$ amount from 40 to $47 \mathrm{mg} \mathrm{NaOH} / \mathrm{g}_{\mathrm{TS}}$ resulted in a $\mathrm{pH}$ jump of nearly one unit, without significant effect on COD solubilisation. Considering this $\mathrm{pH}$ transition (and its final value), a dose of $40 \mathrm{mg} \mathrm{NaOH}_{\mathrm{H}} / \mathrm{g}_{\mathrm{TS}}$ could be selected as a critical $\mathrm{NaOH}$ dose for chemical disintegration of sludge.

\subsubsection{Comparison of sole ultrasonic and sole chemical pretreatment} of sludge

Fig. 2 recalls the main results of US treatment carried out on the mixed sludge using $P_{\mathrm{US}}$ of $150 \mathrm{~W}$, with various thermal conditions (isothermal/adiabatic) and external pressures (atmospheric/ optimal value of 2 bar) (Le et al., 2013).

Conversely to chemical treatment which showed a fast COD solubilisation (after $30 \mathrm{~min}$ as abovementioned), $\mathrm{DD}_{\mathrm{COD}}$ gradually increased during the $2 \mathrm{~h}$ of sonication.

The efficiency of US resulted nearly equally from mechanical and thermal effects induced by cavitation as $\mathrm{DD}_{\mathrm{COD}}$ of mixed sludge obtained dropped from $32.8 \%$ under adiabatic conditions to $19.1 \%$ at a controlled temperature of $28{ }^{\circ} \mathrm{C}$ after $2 \mathrm{~h}$ of sonication. When applying external pressure, the degree of sludge disintegration was slightly improved, by about $10 \%$ at the optimal value of 2 bar.

Table 2

Chemical pretreatment of mixed sludge (room temperature).

\begin{tabular}{|c|c|c|c|c|c|c|c|}
\hline & \multicolumn{7}{|c|}{ Holding time (min) } \\
\hline & \multirow{2}{*}{$\frac{0.5}{\mathrm{pH}}$} & \multirow{2}{*}{$\frac{10}{\mathrm{DD}_{\mathrm{COD}}(\%)}$} & \multirow{2}{*}{$\frac{20}{\mathrm{DD}_{\mathrm{COD}}(\%)}$} & \multicolumn{2}{|l|}{30} & \multirow{2}{*}{$\frac{40}{\mathrm{DD}_{\mathrm{COD}}(\%)}$} & \multirow{2}{*}{$\frac{117}{\mathrm{DD}_{\mathrm{COD}}(\%)}$} \\
\hline & & & & $\mathrm{pH}$ & $\mathrm{DD}_{\mathrm{COD}}(\%)$ & & \\
\hline Sol. 22 & 9.6 & 6.4 & 7.3 & 8.6 & 9.5 & 10.7 & 12.3 \\
\hline Sol. 40 & 10.2 & 11.5 & 13.3 & 9.4 & 17.0 & 18.3 & 21.0 \\
\hline Sol. 47 & 11.1 & 13.0 & 15.8 & 10.1 & 19.3 & 21.0 & 22.5 \\
\hline Sol. 77 & 12.2 & 24.4 & 26.3 & 11.0 & 29.0 & 30.4 & 33.1 \\
\hline
\end{tabular}

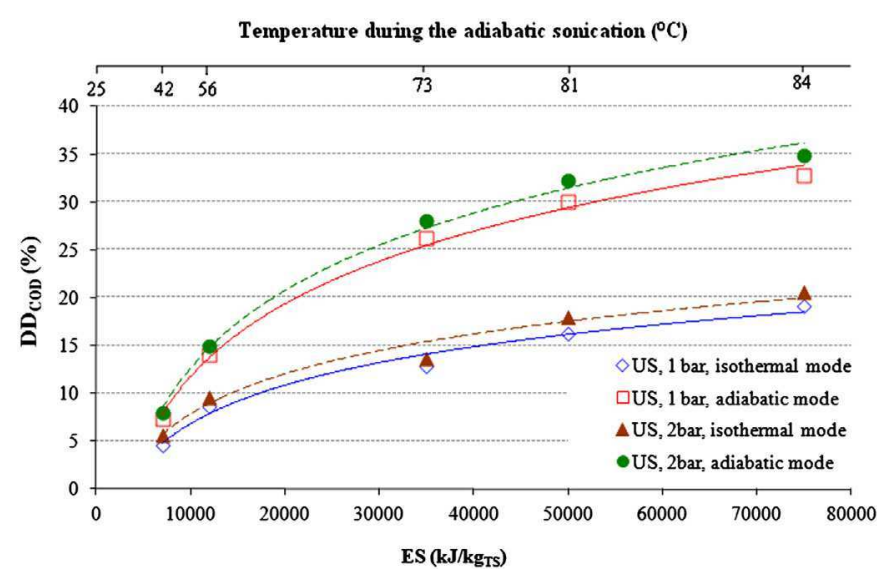

Fig. 2. Mixed sludge disintegration under US pretreatment: evolution of COD solubilisation as a function of applied specific energy (TS $=28 \mathrm{~g} / \mathrm{L}, P_{\mathrm{US}}=150 \mathrm{~W}$ ). The upper $y$-axis indicates the evolution of temperature during the adiabatic sonication (final $T$ for each corresponding ES value).

After 30 min under $\mathrm{NaOH}$ treatment, the volume mean diameter $D[4,3]$ of mixed sludge was $288,247,203$, and $133 \mu \mathrm{m}$ for sol. 22 , sol. 40 , sol. 47 , and sol. 77 , respectively, compared to $370 \mu \mathrm{m}$ for the untreated sample. For the same time under controlled temperature sonication, $D[4,3]$ dropped to about $100 \mu \mathrm{m}$. However, with the exception of sol. 22, a much higher $\mathrm{DD}_{\mathrm{COD}}$ was achieved by chemical treatment. This could be explained that apart from causing the disintegration of floc structures and cell walls, hydroxyl anions also resulted in extensive swelling and subsequent solubilisation of gels in sludge (Kim et al., 2003). The higher the $\mathrm{pH}$, the more easily the processes of natural shape losing of proteins, saponification of lipid, and hydrolysis of RNA occur (Li et al., 2008; Carrère et al., 2010). Obviously, selection of $\mathrm{NaOH}$ dose must also be based on the $\mathrm{pH}$ of sludge after chemical pretreatment that should comply with subsequent treatment - methanisation requiring a narrow range between 6.5 and 8 (Kim et al., 2003).

\subsection{Effect of $\mathrm{NaOH}$ addition prior to sonication}

\subsubsection{Combined chemical - ultrasonic pretreatment of sludge at} atmospheric pressure

Different mixed sludge samples were prepared by adding increasing doses of $\mathrm{NaOH}$ (as per sol. 22 to sol. 77) and letting react for 30 min under stirring before applying US for $2 \mathrm{~h}$.

Fig. 3 compares the final $\mathrm{DD}_{\mathrm{COD}}$ values of the combined pretreatment to those of the US pretreatment, with and without cooling. As expected, alkali-ultrasonic pretreatment was the most effective technique for sludge disintegration, and the resulting efficacy was nearly the sum of individual alkali and US pretreatments when sol. 22 or sol. 40 were kept under isothermal conditions $\left(28{ }^{\circ} \mathrm{C}\right)$. Jin et al. (2009) also observed such a result. Alkalisation significantly reduced the differences observed between the controlled and uncontrolled temperature modes of US treatment. It is also worth noting that under US, the differences resulting from the addition of different $\mathrm{NaOH}$ amounts tended to vanish. Therefore, addition of a small $\mathrm{NaOH}$ dose (as per sol. 22 or sol. 40) should be indeed the best option for the whole process.

\subsubsection{Combined chemical - ultrasonic pretreatment of sludge under pressure}

Some positive effect of external pressure was observed in our previous work, with an optimal pressure of about 2 bar. Hence, some experiments were also carried out under this external pressure value. In the previous experiments (cf. $\S 3.2 .1$ ), after $2 \mathrm{~h}$ of 


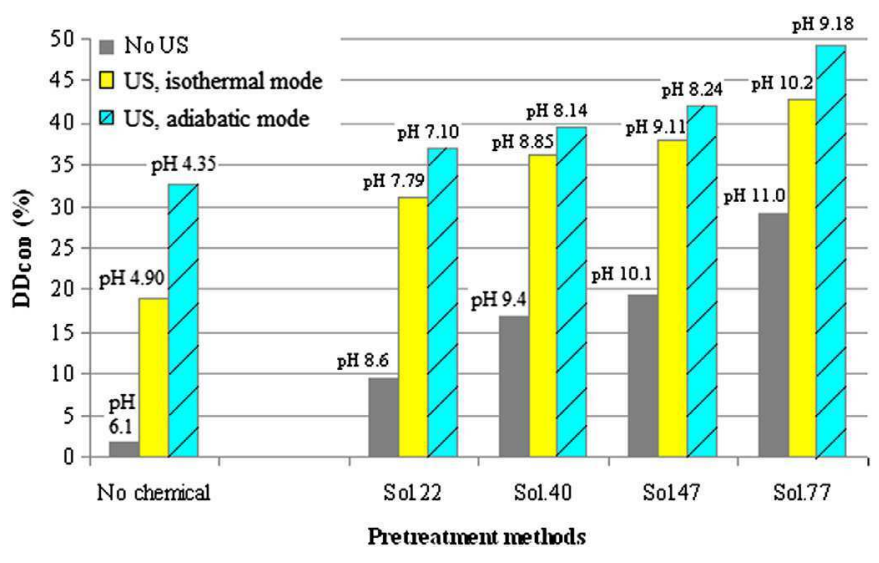

Fig. 3. Comparison of different methods for mixed sludge disintegration (TS $=28 \mathrm{~g} / \mathrm{L}$ ) $P_{\mathrm{US}}=150 \mathrm{~W}$, sonication duration $=117 \mathrm{~min}, \mathrm{NaOH}$ dose $=0-77 \mathrm{mg} \mathrm{NaOH}_{\mathrm{NS}} / \mathrm{g}_{\mathrm{TS}}$ (holding time $=30 \mathrm{~min}$ ), and atmospheric pressure. Final $\mathrm{pH}$ value after treatment is also indicated on top of each corresponding bar.

sonication, the $\mathrm{pH}$ of the different alkalized mixed sludge solutions varied between 7.8 and 10.2 under cooling and between 7.1 and 9.2 under adiabatic condition. The upper values are too high for a subsequent valorisation by methanisation according to the abovementioned $\mathrm{pH}$ range of $\mathrm{AD}$. Therefore, subsequent US experiments at different ES (or sonication duration) combining all parameters (pH adjustment, isothermal/adiabatic modes, and external pressure application) were conducted for sol. 40 only. The results are shown in Fig. 4.

The same conclusions prevailed regarding the effect of temperature and alkalisation, but at 2 bar of external pressure, the overall process was still improved: up to about $46 \%$ of $\mathrm{DD}_{\mathrm{COD}}$ after $2 \mathrm{~h}$ of sonication of sol. 40 . The final $\mathrm{pH}$ of 7.6 was also suitable for AD. The solubilisation performance depicted in Fig. 4 was somewhat lower than that reported by Jin et al. (2009) (about 45\% with $99 \mathrm{mg} \mathrm{NaOH}_{\mathrm{N}} / \mathrm{g}_{\mathrm{TS}}$ and ES $\left.12000 \mathrm{~kJ} / \mathrm{kg}_{\mathrm{TS}}\right)$ and Kim et al. (2010) (50-60\% for $\mathrm{pH} \mathrm{9-10} \mathrm{and} \mathrm{ES}<30,000 \mathrm{~kJ} / \mathrm{kg}_{\mathrm{TS}}$ ). Apart from the higher $\mathrm{NaOH}$ doses applied, it could be due to different experimental conditions as compared to the present work: substrates (WAS (Jin et al., 2009; Kim et al., 2010) vs. mixed sludge), US apparatus (probe system (Jin et al., 2009; Kim et al., 2010) vs. cup-horn system), US intensity and US density reflected by $P_{\mathrm{US}}$, probe diameter, and volume of sludge per experiment ( $300 \mathrm{~W}$ (Kim et al., 2010) vs. $150 \mathrm{~W} ; 6 \mathrm{~mm}$ (Jin et al.,

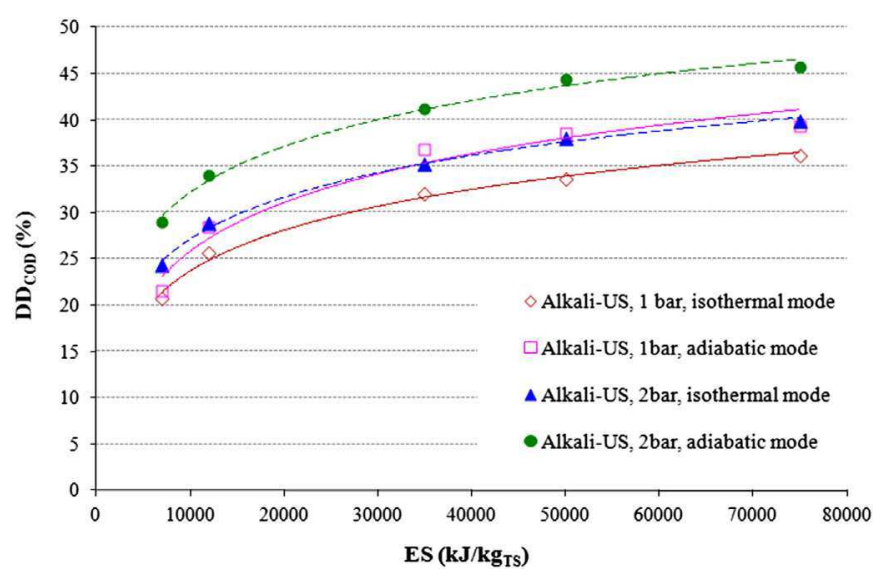

Fig. 4. Mixed sludge disintegration under alkali-US pretreatment: evolution of COD solubilisation as a function of applied specific energy (TS $=28 \mathrm{~g} / \mathrm{L}, P_{\mathrm{US}}=150 \mathrm{~W}, \mathrm{NaOH}$ dose $=40 \mathrm{mg}_{\mathrm{NaOH}} / \mathrm{g}_{\mathrm{TS}}$ ).

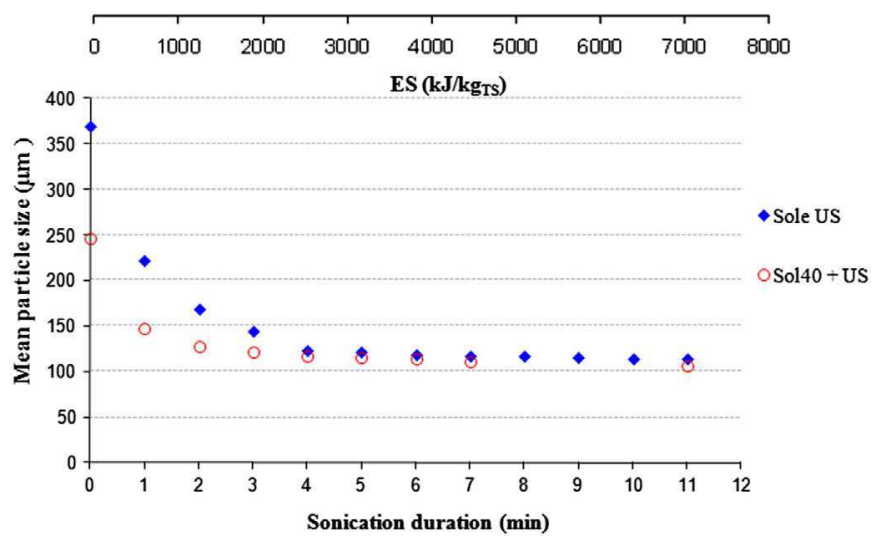

Fig. 5. Mean particle size evolution of mixed sludge (based on $D[4,3]$ ) during the early stage of (alkali-)US pretreatment: $P_{\mathrm{US}}=150 \mathrm{~W}$, controlled $T\left(28^{\circ} \mathrm{C}\right)$, and atmospheric pressure.

2009) vs. $35 \mathrm{~mm}$ of probe diameter; $0.1 \mathrm{~L}$ (Jin et al., 2009; Kim et al., 2010) vs. 0.5 L of sludge).

\subsection{Particle size reduction}

As abovementioned in $\S 3.1 .2$, US pretreatment is very effective in reducing the sludge particle size, which accelerates the hydrolysis stage of $A D$ and enhances the degradation of organic matters. Main reduction of $D[4,3]$ was observed within a much shorter duration compared to the time required for a significant COD release in the aqueous phase. Other works (Chu et al., 2001; Gonze et al., 2003; Show et al., 2007) came to the same conclusion.

In order to observe more precisely the particle size reduction, experiments were carried out with particle size sampling at much shorter time of sonication. The results (Fig. 5) show that the combination of US and chemical treatment accelerated the size reduction, but the final $D[4,3]$ value was almost the same, about $100 \mu \mathrm{m}$.

According to the work of Gonze et al. (2003), the particle size distributions were deconvoluated into five populations, each following a log-normal distribution. The treatment was performed using OriginPro 8.6 (OriginLab). An example is given in Fig. 6 for the raw mixed sludge: a very small extra peak might be distinguished around $1 \mu \mathrm{m}$, but its contribution was always so low that it could not be adequately detected. Therefore, its contribution was neglected.

Fig. 7a shows the evolution of each population contribution during the US treatment: two macro-floc populations - population

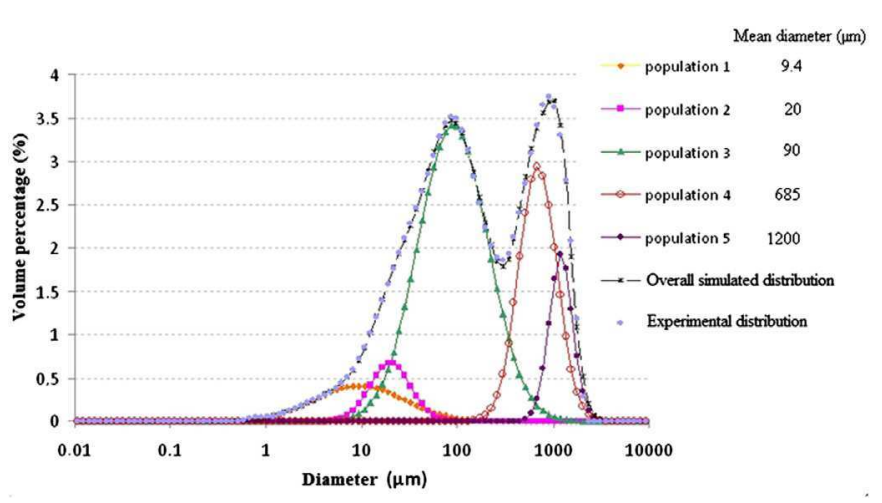

Fig. 6. Deconvolution of PSD of raw mixed sludge 

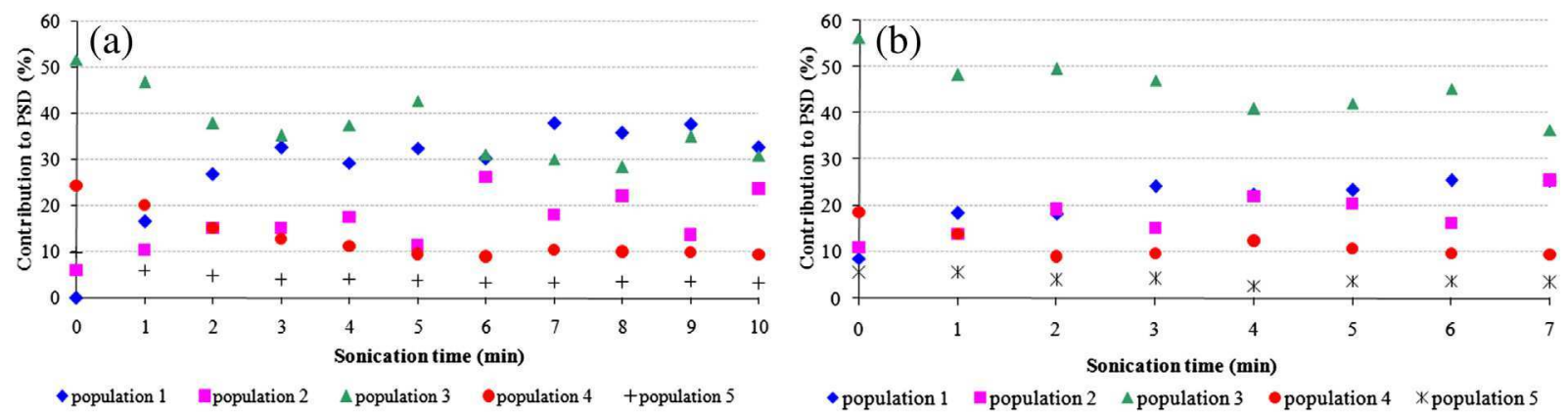

Fig. 7. Contribution of each population to PSD of mixed sludge during short sonication: (a) without addition of $\mathrm{NaOH}$ and (b) $u$ sing $40 \mathrm{mg} \mathrm{NaOH} / \mathrm{g}_{\mathrm{TS}}\left(P_{\mathrm{US}}=150 \mathrm{~W}\right.$, controlled $T$ at $28^{\circ} \mathrm{C}$, and atmospheric pressure).

4 and 5 of $685 \mu \mathrm{m}$ and $1200 \mu \mathrm{m}$, respectively - could be distinguished in the mixed sludge, both their mean diameter and contribution significantly decreased during the first 4 min of sonication. Their diameter dropped to about $400 \mu \mathrm{m}$ and $650 \mu \mathrm{m}$, respectively, while their contribution was divided by a factor 2.5 to 3. Conversely, the size of populations 1 to 3 (about $10 \mu \mathrm{m}, 20 \mu \mathrm{m}$, and $90 \mu \mathrm{m}$, respectively) remained almost constant during short US treatment. It seems thus that the decrease of the largest macroflocs proceeded mainly according to erosion mechanism, while population 3 was disrupted into micro-flocs (population 1).

After the $30 \mathrm{~min} \mathrm{NaOH}$ pretreatment (using $40 \mathrm{mg}_{\mathrm{NaOH}} / \mathrm{g}_{\mathrm{TS}}$ ), the diameters of population 1 and 4 were reduced by about $20 \%$ as compared to raw mixed sludge and the contributions of populations 4 and 5 were reduced by a factor 1.3 and 1.8 , respectively (in favour of population 2) (Fig. 7b). However, their evolution under subsequent sonication remained similar as without $\mathrm{NaOH}$ addition. In this condition, mean diameter of population 4 and 5 dropped to 400 and $600 \mu \mathrm{m}$, respectively, while that of populations 1 to $3 \mathrm{kept}$ almost unchanged.

For a further comprehension of the relationship between mean particle size reduction and COD solubilisation, additional experiments with and without $\mathrm{pH}$ adjustment $\left(40 \mathrm{mg}_{\mathrm{NaOH}} / \mathrm{g}_{\mathrm{TS}}\right)$ were carried out in the following conditions: US were applied during the first minute or the first $4 \mathrm{~min}$, and then only the stirrer was continuously operated under cooling. Despite these two sonication durations resulted in distinct $D[4,3]$, especially under natural $\mathrm{pH}$ (Fig. 5), no differences were observed in terms of $\mathrm{DD}_{\mathrm{COD}}$ afterwards (Fig. 8). These short US pretreatments only provided a small initial jump of COD release, but did not modify its evolution. Therefore, it proves that the strong reduction of mean particle size observed at low ES was not sufficient to affect COD solubilisation as expected by the different process dynamics.

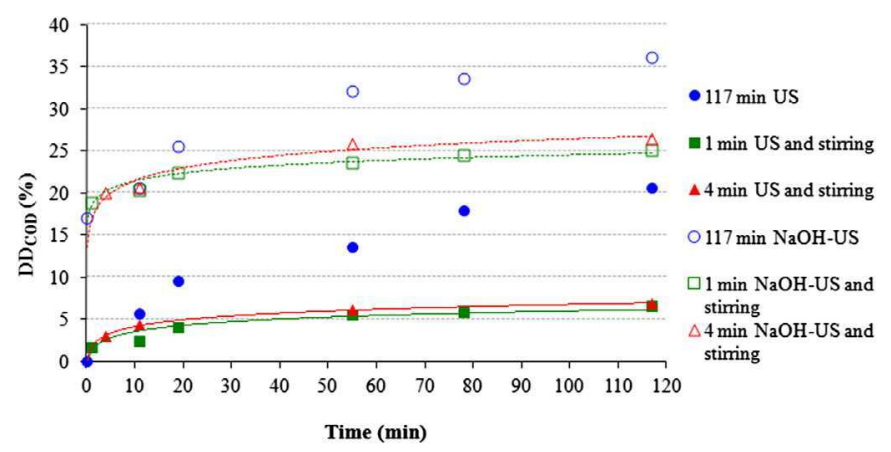

Fig. 8. Effect of short sonication time on mixed sludge disintegration with and without addition of $\mathrm{NaOH}\left(40 \mathrm{mg}_{\mathrm{NaOH}} / \mathrm{g}_{\mathrm{TS}}\right): P_{\mathrm{US}}=150 \mathrm{~W}$, controlled $T\left(28^{\circ} \mathrm{C}\right)$, and atmospheric pressure.

\section{Conclusions}

This work proved that US pretreatment of sewage sludge benefits from the combined effects of generated heat, mild alkalisation, and also external pressure application, which was not investigated in earlier works. It was confirmed that under controlled temperature condition, US and alkali pretreatments have distinct mechanisms of action on sludge, resulting in different kinetics of COD release and additive effects for low $\mathrm{NaOH}$ dose. Conversely, the chemical pretreatment hided the positive effect of the heat generated by US under adiabatic condition. It was also shown that the fast reduction of sludge mean particle size observed at low ES is not sufficient to explain the effect of US on COD solubilisation.

Addition of low $\mathrm{NaOH}$ dose, between 22 and $40 \mathrm{mg}_{\mathrm{NaOH}} / \mathrm{g}_{\mathrm{TS}}$, is recommended, that significantly improved COD release under subsequent US treatment while resulting in a final $\mathrm{pH}$ value suitable for subsequent methanisation. In the later condition, $\mathrm{DD}_{\mathrm{COD}}$ yield reached up to $46 \%$ at $75,000 \mathrm{~kJ} / \mathrm{kg}_{\mathrm{TS}}$ as compared to $35 \%$ for sole US.

\section{Acknowledgements}

The authors acknowledge the financial support from the Ministry of Education and Training of Vietnam and Institut National Polytechnique of Toulouse (France). They also thank Alexandrine BARTHE (Ginestous WWTP), Ignace COGHE, Jean-Louis LABAT, Jean-Louis NADALIN, Lahcen FARHI (LGC), Christine REY-ROUCH (SAP, LGC), Xavier LEFEBVRE, Anil SHEWANI (INSA, LISBP, Toulouse), and SINAPTEC company for technical and analytical support.

\section{References}

APHA, AWWA, WEF, 2005. Standard Methods for the Examination of Water and Wastewater, twenty-first ed. American Public Health Association, Washington, D.C.

Apul, O.G., 2009. Municipal Sludge Minimization: Evaluation of Ultrasonic and Acidic Pretreatment Methods and Their Subsequent Effects on Anaerobic Digestion. Thesis of Master Degree. Middle East Technical University, Turkey. http://etd.lib.metu.edu.tr/upload/12610366/index.pdf (accessed 28.07.12.).

Bieganowski, A., Lagod, G., Ryzak, M., Montusiewicz, A., Chomczynska, M., Sochan, A., 2012. Measurement of activated sludge particle diameters using laser diffraction method. Ecol. Chem. Eng. S 19 (4), 567-608.

Bunrith, S., 2008. Anaerobic Digestibility of Ultrasound and Chemically Pretreated Waste Activated Sludge. Thesis of Master Degree. Asian Institute of Technology, Thailand. www.faculty.ait.ac.th/visu/Data/AIT-Thesis/Master Thesis Final/ Bunrith.pdf (accessed 28.07.12.).

Carrère, H., Dumas, C., Battimelli, A., Batstone, D.J., Delgenès, J.P., Steyer, Ferrer, I., 2010. Pretreatment methods to improve sludge anaerobic degradability: a review. J. Hazard. Mater. 183, 1-15.

Chu, C.P., Chang, B.V., Liao, G.S., Jean, D.S., Lee, D.J., 2001. Observations on changes in ultrasonically treated waste-activated sludge. Water Res. 35, 1038-1046.

Cum, G., Gallo, R., Spadaro, A., 1988. Effect of static pressure on the ultrasonic Activation of chemical reactions. Selective oxidation at benzylic carbon in the liquid phase. J. Chem. Soc. Perkin Trans. 2, 375-383. 
Govoreanu, R., Saveyn, H., Van der Meeren, P., Nopens, I., Vanrolleghem, P.A., 2009 A methodological approach for direct quantification of the activated sludge floc size distribution by using different techniques. Water Sci. Technol. 60 (7), 1857-1867.

Gonze, E., Pillot, S., Valette, E., Gonthier, Y., Bernis, A., 2003. Ultrasonic treatment of an aerobic sludge in batch reactor. Chem. Eng. Process 42, 965-975.

Jin, Y., Li, H., Mahar, R.B., Wang, Z., Nie, Y., 2009. Combined alkaline and ultrasonic pre-treatment of sludge before aerobic digestion. J. Environ. Sci. (China) 21 279-284.

Kidak, R., Wilhelm, A.M., Delmas, H., 2009. Effect of process parameters on the energy requirement in ultrasonical treatment of waste sludge. Chem. Eng. Process 48, 1346-1352.

Kim, D.H., Jeong, E., Oh, S.E., Shin, H.S., 2010. Combined (alkaline + ultrasonic) pretreatment effect on sewage sludge disintegration. Water Res. 44, 3093-3100.

Kim, J., Park, C., Kim, T.H., Lee, M., Kim, S., Kim, S.W., Lee, J., 2003. Effects of various pretreatments for enhanced anaerobic digestion with waste activated sludge. . Biosci. Bioeng. 95 (3), 271-275.

Le, N.T., Julcour-Lebigue, C., Delmas, H., 2013. Ultrasonic sludge pretreatment under pressure. Ultrason. Sonochem. 20, 1203-1210.

Li, H., Jin, Y., Mahar, R., Wang, Z., Nie, Y., 2008. Effects and model of alkaline waste activated sludge treatment. Bioresour. Technol. 99, 5140-5144.

Li, H., Jin, Y., Mahar, R., Wang, Z., Nie, Y., 2009. Effects of ultrasonic disintegration on sludge microbial activity and dewaterability. J. Hazard. Mater. 161, 1421-1426.
Liu, X., Liu, H., Chen, J., Du, G., Chen, J., 2008. Enhancement of solubilisation and acidification of waste activated sludge by pre-treatment. Waste Manage. 28 , $2614-2622$.

Minervini, D., 2008. The Potential of Ultrasound Treatment for Sludge Reduction. $\mathrm{PhD}$ thesis. Cranfield University, UK. https://dspace.lib.cranfield.ac.uk/ bitstream/1826/4085/1/Minervini_Thesis_2008.pdf (accessed 24.04.13.).

Neyens, E., Baeyens, J., Weemas, M., De Heyder, B., 2003. Hot acid hydrolysis as a potential treatment of thickened sewage sludge. J. Hazard. Mater. 98 (1-3), 275-293.

Nickel, K., Neis, U., 2007. Ultrasonic disintegration of biosolids for improved biodegradation. Ultrason. Sonochem. 14, 450-455.

Pilli, S., Bhunia, P., Yan, S., LeBlanc, R.J., Tyagi, R.D., Surampalli, R.Y., 2011. Ultrasonic pretreatment of sludge: a review. Ultrason. Sonochem. 18, 1-18.

Show, K.Y., Mao, T., Lee, D.J., 2007. Optimization of sludge disruption by sonication. Water Res. 41, 4741-4747.

Thompson, L.H., Doraiswamy, L.K., 1999. Sonochemistry: science and engineering. Ind. Eng. Chem. Res. 38, 1215-1249.

Valo, A., Carrère, H., Delgenès, J.P., 2004. Thermal, chemical and thermo-chemical pretreatment of waste activated sludge for anaerobic digestion. J. Chem. Technol. Biotechnol. 79 (11), 1197-1203.

Woodard, S.E., Wukash, R.F., 1994. A hydrolysis/thickening/filtration process for the treatment of waste activated sludge. Water Sci. Technol. 30 (3), 29-38. 